\title{
Statiner og amming ved familiær hyperkolesterolemi
}

\author{
Kvinner med familiær hyperkolesterolemi anbefales i dag å avslutte ammingen når de skal starte statin- \\ behandling etter svangerskap. Vi mener at dagens praksis kan være uheldig.
}

Behandling med kolesterolsenkende medikamenter anbefales i dag ikke til kvinner som ammer (1). Kvinner med familiær hyperkolesterolemi som ammer, må derfor avslutte ammingen før behandling med statiner kan startes opp. Økende kunnskap om morsmelkens og ammingens positive helseeffekter gjør at vi oftere enn før stiller spørsmål ved om barn og mor utsettes for økt helserisiko når kvinnen slutter å amme fordi hun skal behandles med et legemiddel.

Mange legemidler kan brukes i ammeperioden (2). Regionale legemiddelinformasjonssentre (RELIS) og Nasjonal kompetansetjeneste for amming gjør daglig nytte-risiko-vurderinger av legemiddelbruk i ammeperioden. Det har vi også gjort for å kartlegge nytten av statinbruk i ammeperioden i forhold til mulig risiko ved legemiddeleksponering hos barnet.

\section{Familiær hyperkolesterolemi hos gravide og ammende}

Familiær hyperkolesterolemi (FH) gir økt risiko for prematur hjerte- og karsykdom og dødsfall dersom tilstanden forblir ubehandlet (3). I Norge har prevalensen tidligere vært estimert til 1:300 (4). En ny studie fra Danmark indikerer en prevalens på 1:217 $(3,5)$. Dette innebærer at det finnes mellom 4000 og 5500 kvinner med familiær hyperkolesterolemi i fertil alder her i landet (6). I 2015 var det 2930 kvinner i aldersgruppen 15-40 år som fikk resept på et statin (7).

Dagens anbefaling er at statiner skal seponeres tre måneder før man forsøker å bli gravid og at de ikke skal brukes under svangerskap og amming (8). For hvert svangerskap vil en kvinne med familiær hyperkolesterolemi være uten statinbehandling i minimum 12-15 måneder, ofte lenger, avhengig av hvor lang tid hun bruker på å bli gravid. Flere studier viser at disse kvinnene får svært høye lipidverdier i denne perioden $(9,10)$.

Man vet ikke nok om hva høye lipidverdier under graviditeten betyr for kvinnens og barnets kardiovaskulære risiko. Enkeltstående kasuistikker har vist større økning av intima media-tykkelse i arterier i løpet av svangerskapet hos dem med familiær hyperkolesterolemi enn hos ikke-gravide med tilstanden i samme tidsperiode (11). FELIC-studien viste at hyperkolesterolemi hos kvinnen under svangerskapet ga økt risiko for aterosklerose hos barnet (12).

Dyrestudier har vist at statinbehandling hos svangre og ammende mus har en guns- tig kardioprotektiv effekt - ikke bare hos den drektige, men også hos avkommet (13, 14). Man har begrenset kunnskap om bruk av statiner i svangerskapet hos kvinner med familiær hyperkolesterolemi, men det er så langt ikke vist noen sikker fosterskadelig effekt av statiner $(1,15)$. Statiner er for øvrig også forsøkt på gravide som forebyggende behandling mot preeklampsi (16).

\section{Statiner og overgang til morsmelk} Alle legemidler passerer over i morsmelken, men de fleste gjør det i liten grad (17). Det er en stor fortynningseffekt av legemidlet i morens kropp slik at dosene i morsmelk blir

\section{«Selv om morsmelken skulle inneholde sta- tiner, vil den syste- miske absorpsjonen hos barnet uansett være veldig liten»}

lave. Legemidlets farmakokinetikk har betydning for graden av overgang til morsmelken og absorbsjonen hos barnet. Mange legemidler kan brukes av ammende, og det er sjelden man trenger å avslutte ammingen når kvinnen skal legemiddelbehandles (18).

Noen få legemidler er absolutt kontraindisert ved amming. Det gjelder toksiske og radioaktive substanser som gullpreparater, cytostatika, radiofarmaka og jodbaserte røntgenkontrastmidler. Forsiktighet skal også utvises ved bruk av potente legemidler der det er liten forskjell mellom terapeutisk og toksisk dose og når det gjelder legemidler med effekt på sentralnervesystemet ved bruk utover noen få doser (18).

Statiner har forholdsvis stor molekylstørrelse og høy grad av proteinbinding. Overgangen fra mors serum til morsmelken er derfor relativt liten (17). Statiner metaboliseres i all hovedsak via førstepassasjemetabolisme i leveren og har lav peroral biotilgjengelighet. Selv om morsmelken skulle inneholde statiner, vil den systemiske absorpsjonen hos barnet uansett være veldig liten, med lav risiko for farmakologiske effekter $(17,19)$.
Det er ikke gjort kliniske studier av statinbruk i ammeperioden, men til nå er det ikke publisert data som tyder på at dette er skadelig for diebarn. Barn som er homozygote for familiær hyperkolesterolemigenet blir behandlet med høydose statiner fra før ett års alder og barn som er heterozygote for tilstanden behandles fra 8-10 års alder $(20,21)$.

\section{Statiners effekt på innholdet i morsmelken}

Man vet lite om statiners effekt på morsmelkens innhold av kolesterol og lipider. Kolesterolnivået i morsmelk fra en kvinne homozygot for familiær hyperkolesterolemi-genet var tre ganger så høyt som hos friske kontrollkvinner, ifølge en studie (22). Hvis kolesterolverdien blir normalisert ved statinbruk, er det rimelig å anta at morsmelkens nivå av lipider også vil reduseres til et mer normalt nivå.

Kolesterol er viktig for barnets hjerneutvikling og en viktig bestanddel $i$ alle kroppens celler. Et mulig redusert nivå av kolesterol i morsmelken på grunn av statinbehandling hos mor vil fortsatt gi en betydelig høyere kolesteroldose til barnet enn alternativet, som er morsmelkerstatning.

Vi tror at det kan ha en positiv effekt for både mor og barn at kvinnens kolesterolverdier blir normalisert i ammeperioden. Melkens kvalitet reduseres sannsynligvis ikke, og det er også meget lav risiko for bivirkninger hos barnet med så lav eksponering.

\section{Valg av statin}

Siden kliniske data savnes, bør det ved valg av statiner til ammende tas utgangspunkt i farmakokinetiske betraktninger rundt de enkelte virkestoffene. Rosuvastatin og pravastatin er begge hydrofile statiner med teoretisk lavere overgang til morsmelk enn lipofile statiner (16). Rosuvastatin har en høyere grad av proteinbinding, høyere molekylvekt og høyere distribusjonsvolum enn pravastatin og kan dermed være å foretrekke $(16,17,23)$

I en kasuistikk med en ammende kvinne som brukte rosuvastatin, ble det funnet lav konsentrasjon av medikamentet i morsmelken, på nivå med konsentrasjonen i morens plasma (24). Barnets relative dose ble beregnet til $0,59 \%$. Generelt sier man at en relativ dose på under $10 \%$ gir liten risiko for bivirkninger hos barnet og at en relativ dose på under $2 \%$ tyder på minimal overgang av legemidlet til morsmelken $(17,19)$. 
I kasuistikken ga en dosering på $40 \mathrm{mg} / \mathrm{dag}$ rosuvastatin til kvinnen en absolutt døgndose i morsmelken på ca. $0,01 \mathrm{mg}$ (24). Med rosuvastatinets lave biotilgjengelighet er det lite sannsynlig at dette legemidlet vil kunne ha noen farmakologisk effekt hos barnet.

\section{Gunstige helseeffekter av amming ved familiær hyperkolesterolemi}

Amming har en rekke gunstige helseeffekter for kvinner $(25,26)$. Det er en kardioprotektiv effekt, med sannsynlig gunstig innvirkning på risikoen for hjerteinfarkt, og redusert risiko for høyt blodtrykk (27). Amming ser også ut til å gi bedre blodsukkerregulering og lipidprofil samt redusert risiko for diabetes type 2 (28-33). Vi tror at dette er spesielt viktig for kvinner med familiær hyperkolesterolemi, som har økt risiko for hjerte- og karsykdom.

Morsmelk er den beste spedbarnsernæringen og viktig for barnets vekst og utvikling. Amming beskytter barnet mot overvekt i barnealder (26), og det er sannsynlig at ammede barn har redusert risiko for diabetes type 1 og type $2(34,35)$. Det er mulig at morsmelken er av ekstra stor betydning for barn av kvinner med familiær hyperkolesterolemi. Siden sykdommen har autosomalt dominant arvegang, vil $50 \%$ av barna arve den. For disse er det sannsynlig at tidlig avvenning fra brystet kan være uheldig.

\section{Konklusjon}

Vi mener at helsefordelene ved at en kvinne med familiær hyperkolesterolemi bruker et statin mens hun ammer oppveier den lave risikoen dette innebærer for barnet. Det er behov for flere studier av statiners overgang til morsmelk og av morsmelkens sammensetning hos kvinner som bruker statiner.

Vår vurdering er at det er trygt og bra for barna til kvinner med familiær hyperkolesterolemi å få melk fra mor - samtidig som hun får adekvat behandling med et statin, fortrinnsvis rosuvastatin. Dette må tillegges betydelig vekt ved den forskningsetiske vurderingen av fremtidige studier. Når det foreligger flere studier, vil man kunne utarbeide nasjonale anbefalinger om bruk av statiner hos kvinner med familiær hyperkolesterolemi i ammeperioden. I mellomtiden kan man gi individuelle råd ut fra vår nytterisiko-vurdering og den enkelte kvinnens ønske om å amme.

\section{Solveig Thorp Holmsen \\ soholm@ous-hf.no \\ Tina Bakkebø \\ Maria Seferowicz \\ Kjetil Retterstøl}

Solveig Thorp Holmsen (f. 1970) er lege i spesialisering i samfunnsmedisin, lege og medisinsk rådgiver ved Nasjonal kompetansetjeneste for amming og overlege ved Oslo skade- legevakt, Oslo universitetssykehus. Hun er master of public health.

Forfatter har fylt ut ICMJE-skjemaet og oppgir ingen interessekonflikter.

Tina Bakkebø (f. 1980) er cand.pharm. og rådgiver RELIS Vest, Haukeland universitetssykehus Forfatter har fylt ut ICMJE-skjemaet og oppgir ingen interessekonflikter.

Maria Seferowicz (f. 1982) er overlege ved akuttmedisinsk avdeling, Lovisenberg Diakonale Sykehus. Tidligere var hun lege/forsker Lipidklinikken. Oslo universitetssykehus. Forfatter har fylt ut ICMJE-skjemaet og oppgir ingen interessekonflikter.

Kjetil Retterstøl (f. 1962) er spesialist i medisinsk biokjemi, professor ved Avdeling for ernæringsvitenskap på Universitetet i Oslo og overlege ved Lipidklinikken ved Oslo univer sitetssykehus. Han leder forskningruppen «Aterosklerose og lipidologi» og er leder ved Senter for klinisk ernæring ved Oslo universitetssykehus og Universitetet i Oslo.

Forfatter har fylt ut ICMJE-skjemaet og oppgir følgende interessekonflikter: Han har mottatt stipend og honorar fra Sanofi, honorar fra Takeda, Chiesi, AstraZeneca, Norsk Cardiologisk Selskap, Den norske legeforening, Amgen, Helsedirektoratet, Milss DA, Oslo Economics, Norsk forskningsråd, men det har ikke vært noe samarbeid med legemiddelindustrien eller andre eller utbetaling av støtte i forbindelse med denne artikkelen.

\section{Litteratur}

1. Bakkebø T. Lipidsenkende midler ved graviditet og amming. Utposten 2014: 43: 46-7.

2. Widnes SF, Bakkebø T. Ikke bruk Felleskatalogen for informasjon om legemidler ved graviditet eller amming! Nor Farmaceut Tidsskr 2014; 122: 24-5

3. Mundal L, Sarancic M, Ose L et al. Mortality among patients with familial hypercholesterolemia: a registry-based study in Norway, 1992-2010. J Am Heart Assoc 2014; 3: e001236.

4. Heiberg A, Berg K. The inheritance of hyperlipoproteinaemia with xanthomatosis. A study of 132 kindreds. Clin Genet 1976: 9: 203-33.

5. Benn M, Watts GF, Tybjærg-Hansen A et al. Mutations causative of familial hypercholesterolaemia: screening of 98098 individuals from the Copenhagen General Population Study estimated a prevalence of 1 in 217. Eur Heart J 2016; 37: 1384-94.

6. Statistisk sentralbyrå. Folkemengd, etter land, kjønn og alder. Nordiske land. 1. januar 2016. http://www.ssb.no/274586/folkemengd-etterland-kjonn-og-alder.nordiske-land.1.januar2016.tal-og-prosent-sa-63 (17.1.2017).

7. (NorPD) R. Reseptregisteret. http://www.reseptregisteret.no/ (17.1.2017)

8. Thorogood M, Seed M, De Mott K. Management of fertility in women with familial hypercholesterolaemia: summary of NICE guidance. BJOG 2009 116: 478-9

9. Avis HJ, Hutten BA, Twickler MT et al. Pregnancy in women suffering from familial hypercholesterolemia: a harmful period for both mother and newborn? Curr Opin Lipidol 2009; 20: 484-90.

10. Amundsen AL, Khoury J, Iversen PO et al. Marked changes in plasma lipids and lipoproteins during pregnancy in women with familial hypercholesterolemia. Atherosclerosis 2006; 189: 451-7.

11. Kusters DM, Homsma SJ, Hutten BA et al. Dilemmas in treatment of women with familial hypercholesterolaemia during pregnancy. Neth J Med 2010; 68: 299-303.
12. Napoli C Glass CK Witztum JL et al. Influence of maternal hypercholesterolaemia during pregnancy on progression of early atherosclerotic lesions in childhood: Fate of Early Lesions in Children (FELIC) study Lancet 1999: 354:1234-41.

13. Elahi MM, Cagampang FR, Anthony FW et al. Statin treatment in hypercholesterolemic pregnant mice reduces cardiovascular risk factors in their offspring. Hypertension 2008; 51: 939-44.

14. Elahi MM, Cagampang FR, Ohri SK et al. Longterm statin administration to dams on high-fat die protects not only them but also their offspring from cardiovascular risk. Ann Nutr Metab 2013; 62: $250-6$.

15. Bateman BT, Hernandez-Diaz S, Fischer MA et al. Statins and congenital malformations: cohort study. BMJ 2015; 350: h1035.

16. Lecarpentier E, Morel O, Fournier T et al. Statins and pregnancy: between supposed risks and theoretical benefits. Drugs 2012; 72: 773-88.

17. Hale TW, Rowe HE. Medications and Mothers Milk. Plano, TX: Hale Publishing, 2014.

18. Nordeng H. Havnen GC, Spigset O. Legemiddelbruk ved amming. Tidsskr Nor Legeforen 2012: 132: $1089-93$

19. Amming og legemidler. Oslo: Norsk legemiddelhåndbok, 2015.

20. Gidding SS, Champagne MA, de Ferranti SD et al. The Agenda for Familial Hypercholesterolemia: A Scientific Statement From the American Heart Association. Circulation 2015; 132: 2167-92.

21. Græsdal A, Bogsrud MP. Holven KB et al. Apheresis in homozygous familial hypercholesterolemia: the results of a follow-up of all Norwegian patients with homozygous familial hypercholesterolemia. J Clin Lipidol 2012; 6: 331 -9.

22. Tsang RC, Glueck CJ, McLain C et al. Pregnancy, parturition, and lactation in familial homozygous hypercholesterolemia. Metabolism 1978; 27: 823-9.

23. Preparatomtale (SPC) Pravachol. Oslo: Statens legemiddelverk, 2015

24. Schutte AE, Symington EA, du Preez JL. Rosuvastatin is transferred into human breast milk: a case report. Am J Med 2013; 126: e7-8.

25. Maternal and economic benefits of breastfeeding www.uptodate.com/contents/maternal-andeconomic-benefits-of-breastfeeding (11.5.2016)

26. Victora CG, Bahl R, Barros AJD et al. Breastfeeding in the 21st century: epidemiology, mechanisms, and lifelong effect. Lancet 2016; 387: 475-90.

27. Schwarz EB, Ray RM, Stuebe AM et al. Duration of lactation and risk factors for maternal cardiovascular disease. Obstet Gynecol 2009; 113: 974-82.

28. Schwarz EB. Infant feeding in America: enough to break a mother's heart? Breastfeed Med 2013; 8 . $454-7$.

29. Stuebe AM, Michels KB, Willett WC et al. Duration of lactation and incidence of myocardial infarction in middle to late adulthood. Am J Obstet Gynecol 2009: 200: 138.e1-8.

30. Gunderson EP. Impact of breastfeeding on maternal metabolism: implications for women with gestational diabetes. Curr Diab Rep 2014; 14: 460

31. Stuebe AM, Rich-Edwards JW, Willett WC et al. Duration of lactation and incidence of type 2 diabetes. JAMA 2005; 294: 2601-10.

32. Aune D, Norat T, Romundstad P et al. Breastfeeding and the maternal risk of type 2 diabetes: a systematic review and dose-response metaanalysis of cohort studies. Nutr Metab Cardiovasc Dis 2014; 24: 107-15

33. Schwarz EB, Brown JS, Creasman JM et al. Lactation and maternal risk of type 2 diabetes: a population-based study. Am J Med 2010; 123: 863.e1-6.

34. Hörnell A, Lagström H, Lande B et al. Breastfeeding, introduction of other foods and effects on health: a systematic literature review for the 5th Nordic Nutrition Recommendations. Food Nutr Res 2013; 57

35. Long-term effects of breastfeeding: a systematic review. Genève: World Health Organization, 2013.

Mottatt 4.10. 2017, første revisjon innsendt 14.2. 2017, godkjent 18.4. 2017. Redaktør: Kari Tveito.

Publisert først på nett. 